\title{
WAWASAN KEINDONESIAAN DALAM TAFSIR AL QUR'AN AL KARIM KARYA MAHMUD YUNUS
}

\author{
KHAIRUNNAS JAMAL \\ Fakultas Ushuluddin Universitas Islam Negeri Sultas Syarif Kasim Riau
}

\begin{abstract}
Tafsir Al Qur'an Al Karim by Mahmud Yunus who is one of the pioneers for the study of tafseer in Indonesian language. As a work of early interpretation, this interpretation of Mahmud Yunus has a peculiarity and gives a unique impression, both from the systematic presentation and the charge in the explorative meaning of the verses of the Qur'an. Among the interesting sides of this commentary are the efforts of the authors to accommodate the phenomena occurring in society at the time. In other words, this commentary is a form of response to the author's anxiety about the problematic common in the Indonesian public, hereinafter referred to as the insight of Indonesianness.
\end{abstract}

Keywords: Mahmud Yunus, Indonesian-ness

\section{A. PENDAHULUAN}

Kajian Al Qur'an dan penafsirannya di Indonesia dapat dikatakan lebih artikulatif jika dibandingkan dengan wilayahwilayah lain di Asia Tenggara yang juga berbahasa Melayu, seperti Malaysia dan Brunei Darussalam. Indonesia dalam kajian ini disebut sebagai centre of Islamic learning bagi wilayah Asia Tenggara yang berlangsung sampai abad ke 20 .
Hal ini ditandai dengan lahirnya karya-karya para ulama Indonesia di bidang Al Qur'an. Diantara karya-karya intelektual Indonesia adalah penterjemahan 'Abdul Rauf Al Fansuri Singkel (w. 1693 M) atas Tafsir Jalâlain atau yang dikenal dengan kitab Tarjumân Al Mustafid , karya asli Imam Muhammad Nawawi Al Bantani (1813-1897) At Tafsîr Al Munîr Lima'âlim At Tanzîl, Muhammad Shalih Darat (18201903) dengan Tafsir Basa Jawi, 
Khairunnas J amal; Wawasan Keindonesiaan Dalam Tafsir Al Qur'an Al Karim Karya Muhammad Yunus

Munawwir Khalil dengan Tafsir Al Qur'ân Hidâyah Ar Rahmân, Ahmad Hasan Bandung dengan Al Furqan: Tafsir Al Qur'ân Al Karîm (1928), Tengku Muhammad Hasbi Ash Shiddiqie (w. 1975) dengan Tafsir An Nûr dan Tafsir Al Bayân, Syaikh Al Haji Bisyri Musthafa dengan Al Ibrîz li Ma'rifati AI Qur'ân Al 'Azîz (1960), HAMKA (19081988) dengan Tafsir Al Azhar, sampai Muhammad Quraish Shihab dengan Tafsir Al Misbah yang fenomenal. (Muhammad Hatta Abdul Fattah Al Indunisi: 2012, 8-59). (Lihat juga Endang Saipul Anwar: 2010, 14).

Selain karya-karya tafsir para intelektual muslim Indonesia di atas, yang tidak boleh dilupakan adalah tafsir asli berbahasa Indonesia lengkap yang pertama yaitu Tafsir Al Qur'an Al Karim karya Mahmud Yunus. (Howard M. Federspiel: 1996, 39) Beliau merupakan seorang ulama yang berasal dari tanah Minangkabau yang telah melakukan pelbagai peran dan aktifitas dalam perkembangan dan pembaharuan (tajdîd) agama Islam di Indonesia baik sebelum maupun setelah kemerdekaan (Eficandara Masril, Mohd. Nasran Mohammad, Muhammad Adib Syamsuddin dan Anwar Fakhri Omar: 2011, 134). Sebagaimana para intelektual lainnya, beliau juga telah melahirkan karya-karya buah pemikirannya dalam jumlah yang cukup banyak, dan hingga saat ini masih dijadikan sebagai rujukan dan bahan kajian, baik yang berbahasa Arab maupun Indonesia.

Dalam karya tafsirnya, Mahmud Yunus menuangkan pendapat dan interpretasinya terhadap Al Qur'an dengan keterangan-keterangan singkat yang dianggap perlu dan cukup mewakili maksud dari ayat yang ditafsirkannya tersebut. Dalam hal ini, setelah membaca karya tafsirnya, kita dapat menemukan hal-hal yang menarik. Selain itu dijumpai pula di dalamnya keunikan dan kesan tersendiri, yaitu adanya wawasan keindonesiaan yang dihadirkan dalam karya tafsir Mahmud Yunus tersebut, yang selanjutnya akan dipaparkan dalam tulisan ini.

\section{B. BIOGRAFI SINGKAT MAHMUD YUNUS}


Mahmud Yunus dilahirkan pada tanggal 10 Februari $1899 \mathrm{M}$ bertepatan dengan 30 Ramadhan $1316 \mathrm{H}$, di desa Sungayang Batusangkar, Kabupaten Tanah Datar Sumatera Barat dan ia wafat pada tanggal pada hari sabtu tanggal 16 Januari 1982 M bertepatan 20 Rabi'ul Awal $1402 \mathrm{H}$. (Ibid, 135) Mahmud Yunus dilahirkan dari keluarga terkemuka di Nagari Sungayang dan memiliki nuansa keagamaan yang kuat. Ayahnya adalah seorang petani bernama Yunus bin Incek dari suku Mandailing, ia menjabat sebagai Imam Nagari dan ibunya bernama Hafsah binti M Thahir dari suku Chaniago bekerja sebagai penenun. (Mahmud Yunus: 1982, 5)

Sejak kecil, Mahmud Yunus sudah memperlihatkan minat dan kecenderungannya yang kuat untuk memperdalam ilmu agama Islam. Melihat bakat yang ada pada Mahmud Yunus, Ibrahim, mamak nya (sebutan bagi paman atau saudara laki-laki dari jalur ibu di dalam adat Minangkabau) yang juga seorang saudagar kaya memberikan dukungan penuh kepadanya termasuk dalam pembiayaan pendidikan, terlebih ayahnya telah meninggal dunia ketika Mahmud Yunus masih kecil dan belum mumayyiz.

Mahmud Yunus memulai pendidikan agamanya dengan belajar mengaji di surau, layaknya lelaki Minang masa itu pada umumnya. Pada awalnya, beliau belajar dengan kakeknya sendiri, Muhammad Thaher bin Muhammad Ali dengan gelar Engku Gadang. Di surau inilah ia tahu bagaimana cara shalat, puasa dan membaca Al Qur'an dengan benar. Sehingga pada tahun 1908 M, warga Nagari Sungayang membuka Sekolah Desa Mamud Yunus pun tertarik untuk memasuki sekolah ini. Dengan demikian mulailah Mahmud Yunus bersekolah. la pun mengikuti pelajaran di sekolah desa pada tengah hari, tanpa meninggalkan tugas di surau kakeknya untuk mengajar AI Quran pada malam harinya. Rutinitas seperti ini dijalani oleh Mahmud Yunus dengan tekun dan penuh prestasi. Namun karena ketidakpuasan pada pendidikan 
Khairunnas J amal; Wawasan Keindonesiaan Dalam Tafsir Al Qur'an Al Karim Karya Muhammad Yunus

disekolah ini ia hanya menjalaninya selama tiga tahun.

Pada masa yang sama, Syekh Haji Muhammad Thaib Umar (tokoh mujaddid dari Minangkabau dan beliau termasuk sebagai Kaum Muda/Reformis) membuka Madras School (Sekolah Surau) di Surau Tanjung Pauh Sungayang. (M Sanusi Latif: 1981, 90) Di madrasah ini Mahmud Yunus mempelajari berbagai pelajaran, seperti Bahasa Arab, fiqh, balaghah, tasawuf, berhitung (menurut sistem ahli hisab Arab/ sistem faraidh). Berkat kesungguhannya, Mahmud diminta menjadi guru pembantu dan mengajarkan 5 sampai 6 orang. Mahmud Yunus bukan saja mengajarkan kitab-kitab yang telah dipelajarinya, bahkan juga mengajarkan kitab-kitab yang belum pernah dipelajarinya sama sekali. Sekalipun kitab-kitab yang cukup berat untuk ukuran seusianya seperti: Al Mahalli, Alfiah Ibnu 'Aqil dan Jam'u Al Jawami'. (Sulaiman Ibrahim: 2011, 7-8)

$$
\text { Mahmud Yunus merasa }
$$
belum puas terhadap wawasan dan keilmuan yang didapatnya selama ini, sehingga setelah beliau berkesempatan menunaikan ibadah haji ke Makkah pada tahun $1924 \mathrm{M}$, beliau berkeinginan untuk melanjutkan pendidikannya ke tingkat yang lebih tinggi di Negara Timur Tengah, yaitu Mesir. Setidaknya ada dua alasan penting mengapa Mahmud Yunus hendak pergi belajar ke Timur Tengah, khususnya Mesir, yaitu: Pertama, hendak menambah ilmu pengetahuan, terutama pengetahuan umum yang biasa diajarkan di sekolah-sekolah menengah umum. Kedua, hendak menyelidiki keadaan ulama-ulama di Mesir. Adakah di sana ulama kaum muda dan ulama kaum tua seperti di Indonesia? Dan hendak mempelajari dalil-dalil mereka masing-masing, mana yang lebih kuat (Eficandara Masril, Mohd. Nasran Mohammad, Muhammad Adib Syamsuddin dan Anwar Fakhri Omar: 2011, 137).

Maka pada tahun 1924 M, Mahmud Yunus mendaftar sebagai salah seorang pelajar Indonesia yang belajar di Universitas Al Azhar. Di Mesir, Mahmud Yunus kembali memperlihatkan prestasi 
yang istimewa. Sehingga setelah satu tahun masa belajar, Mahmud Yunus mencoba kemampuannya dengan masuk ujian akhir untuk menamatkan pendidikan di Universitas Al Azhar dan mendapatkan Syahadah 'Alimiyah sebagai ijazah tertinggi di Universitas Al Azhar semasa itu. Padahal ujian ini merupakan ujian akhir bagi pelajar yang telah belajar sekurang-kurangnya 12 tahun (Ibtidaiyyah 4 tahun, Tsanawiyyah 4 tahun dan 'Aliyah 4 tahun). Ada 12 cabang ilmu yang diujikan dalam ujian akhir tersebut dan kesemuanya itu telah dikuasai Mahmud Yunus pada waktu belajar di tanah air, sebagaimana dicatatkannya: "Kalau hanya ilmu itu saja yang akan diuji, saya sanggup masuk ujian itu. Karena keduabelas macam ilmu itu telah saya pelajari di Indonesia, bahkan telah saya ajarkan beberapa tahun lamanya (1915-1923)" (Mahmud Yunus: 1982, 28)

Ujian ini dapat diikutinya dengan baik dan berhasil lulus serta mendapatkan ijazah (syahadah) 'Alimiyyah pada tahun yang sama tanpa melalui proses pendidikan. Berbekal ijazah ini, beliau kemudian memasuki Darul 'Ulum 'Ulya Mesir (Darul 'Ulum 'Ulya adalah Sekolah Tinggi pemerintah Mesir untuk menghasilkan guru-guru agama dan bahasa Arab yang akan mengajar di sekolah-sekolah pemerintah. Lihat Mahmud Yunus: 2004, III.) Pada tahun 1925 ia berhasil memasuki lembaga pendidikan yang merupakan Madrasah 'Ulya (setingkat perguruan tinggi) agama yang juga mempelajari pengetahuan umum. la memilih jurusan Tadris (Keguruan), dan diceritakan bahwa pada waktu itu Mahmud adalah satu-satunya mahasiswa pertama dari Indonesia dan mahasiswa asing yang berhasil menyelesaikan hingga ke tingkat IV di Darul 'Ulum dan ia pun kembali ke tanah air pada tahun 1931

Sepulangnya dari Mesir, Mahmud Yunus mengabdikan hampir seluruh sisa hidupnya di dalam dunia pendidikan. Pendidikan Islam adalah jalur profesi yang dipilinnya, dan kemudian pilihan itulah yang memantapkan setiap langkah 
Khairunnas J amal; Wawasan Keindonesiaan Dalam Tafsir Al Qur'an Al Karim Karya Muhammad Yunus

dalam karir yang dilaluinya dengan bekal dan pengaplikasian ilmu yang di dapatnya selama di Mesir. Berikut adalah beberapa karir yang dilalui oleh Mahmud Yunus: memimpin Al Jami'ah Al Islamiyyah di Sungayang selama 2 tahun (1931-1932), memimpin Normal Islam di Padang, memimpin Sekolah Tinggai Islam di Padang (1940-1944), mendirikan dan memimpin Sekolah Menengah Islam (SMI) di Bukittinggi (1946), memimpin IAIN Imam Bonjol di Padang (Rektor pertama) (19671970). (Firdaus: 2011, 52-60) Sedangkan dalam kehidupan rumah tangganya, Mahmud Yunus tercatat pernah menikah dengan lima orang istri dan beliau memiliki anak sebanyak 18 orang. (lbid, 52-60)

Awal tahun 1970 kesehatan Mahmud Yunus menurun dan bolak balik masuk rumah sakit. Tahun 1982, dia memperoleh gelar Doctor Honoris Causa di bidang ilmu Tarbiyah dari IAIN Jakarta atas karya-karyanya dan jasanya dalam pengembangan pendidikan Islam di Indonesia. Pada tahun 1982, Mahmud Yunus meninggal dunia.
Selama hidupnya beliau termasuk orang yang produktif dalam menulis berbagai karya-karya yang kemudian dipublikasikan baik berbahasa Indonesia maupun berbahasa Arab, setidaknya tidak kurang dari 43 karya dalam berbagai disiplin ilmu, seperti: pendidikan, bahasa Arab, fiqh dan ushul fiqh, tafsir, sejarah, perbandingan agama, tauhid, akhlak dan lain-lain.

\section{MENGENAL TAFSIR AL QUR'AN AL KARIM}

\section{Latar belakang dan sejarah penulisan}

Minat Mahmud Yunus terhadap studi Al Qur'an serta bahasa Arab telah menimbulkan hasrat besar dalam dirinya. Sehingga Pada tahun 1922, beliau mulai menterjemahkan Al Qur'an dan diterbitkan dengan huruf ArabMelayu untuk memberi pemahaman bagi mayarakat yang belum begitu paham bahasa Arab. Meskipun waktu itu umumnya ulama Islam mengatakan haram menterjemah Al Qur'an, tetapi beliau sekali tidak terpengaruh bantahan tersebut dan beliaupun 
Al-Fikra: J urnal IImiah Keislaman, Vol. 16, No. 1, J anuari - J uni, 2017 (28 - 44)

tetap melanjutkan usahanya Ketika belajar di Darul 'Ulum beliau menterjemahkan AI Quran Al Karim mendapatkan pelajaran dari Syaikh tersebut. (Mahmud Yunus: 2004, di sana, bahwa menterjemahkan $\mathrm{Al}$ III.)

Karya ini merupakan salah satu pionir bagi karya dalam kajian Al Qur'an di Indonesia dalam bentuk baru, yaitu dilihat dari sudut keberanian menampilkan terjemahan Al Qur'an di tengahtengah masyarakat yang masih menganggap haram menterjemahkan Al Qur'an di luar bahasa Arab. Karena menurut gagasan mayoritas dalam ortodoksi Islam, bahwa terjemahan AI Quran dalam pengertian yang sebenarnya dari kata tersebut adalah suatu kemustahilan. Gagasan ini terutama didasarkan pada karakter i'jaz (keunikan) Al Quran yang tidak bisa diimitasi atau ditandingi manusia dengan cara apapun. Menurut sudut pandang ini, karakteristik tersebut akan hilang dalam terjemahan Al Quran, karena terjemahan dibuat oleh manusia. (Taufik Adnan Kamal: 2011, 395)

Namun usaha Mahmud

Yunus tersebut terhenti, karena beliau pergi melanjutkan studinya ke Mesir pada tahun 1924 M.

Qur'an itu hukumnya adalah mubah (boleh), bahkan dianjurkan atau termasuk fardhu kifayah dengan tujuan untuk menyampaikan dakwah Islamiyah kepada bangsa asing yang tidak mengetahui bahasa Arab. Karena bagaimana mungkin dapat menyampaikan kitabullah kepada mereka, jika tidak diterjemahkan ke dalam bahasa mereka. ((Mahmud Yunus: 2004, III.) Dengan menerima pelajaran tersebut membuat Mahmud Yunus merasa berbesar hati, karena hal itu sesuai dengan usaha menterjemahkan Al Qur'an yang selama ini beliau tekuni.

Setelah kembali dari Mesir, maka dengan berbagai ilmu yang telah diserap pada bulan Ramadhan tahun $1354 \mathrm{H}$ (Desember 1935) beliau mulai kembali menterjemahkan Al Quran dan disertai tafsir ayat-ayatnya yang dianggap penting yang kemudian beliau beri nama : Tafsir Al Quran Al Karim. 
Khairunnas J amal; Wawasan Keindonesiaan Dalam Tafsir Al Qur'an Al Karim Karya Muhammad Yunus

Dengan susah payah karya tafsir tersebutpun di terbitkan 2 juz setiap bulan. Sedang dalam menterjemahkan juz 7 sampai dengan 18 Mahmud Yunus dibantu oleh H.M.K. Bakry. Sehingga pada bulan April 1938 dengan pertolongan Allah Ta'ala selesailah terjemahan Al Qur'an dan tafsirnya lengkap 30 juz dan didistribusikan ke seluruh Indonesia.

Setelah Indonesia merdeka, pada tahun 1950 dengan petunjuk menteri Agama pada waktu itu Wahid Hasyim, salah seorang penerbit Indonesia berkeinginan untuk menerbitkan Tafsir Al Quran Al Karim ini dengan mendapatkan fasilitas kertas dari Menteri Agama dan di cetak sebanyak 200.000 eksemplar. kritikan dari Ulama Yogyakarta, supaya pencetakan Tafsir Al Quran Al Karim ini dihentikan. Kritikan itu dikirim kepada Menteri Agama RI, akan tetapi beliau sendiri tidak menerima kritikan tersebut. Boleh jadi karena kritikan itu karena sebab-sebab yang lain, pemilik percetakan itu tidak mau melanjutkan mencetak Tafsir Al Quran Al Karim ini, padahal pada waktu itu sudah mulai dicetak dengan jumlah yang cukup banyak. Akhirnya diambil alih oleh M. Baharata direktur percetakan Al Ma'arif Bandung, kemudian Tafsir ini dicetak dan di terbitkan sebanyak 200.000 eksemplar dan dijualnya dengan harga Rp. 21 per eksemplar.

Ditegaskan oleh Mahmud Yunus bahwa tafsir ini yang juga disertai dengan kesimpulan isi Al Quran, bukanlah merupakan tejemahan dari kitab bahasa arab, melainkan hasil penelitiannya sejak berusia 20 tahun sampai saat itu berumur 73 tahun. Sebab itu tafsir ini berbeda dengan tafsir-tafsir yang lain pada masa itu. Dalam tafsir ini yang paling dipentingkan ialah menerangakan dan menjelaskan petunujuk-petunjuk yang termaktub dalam Al Quran untuk diamalkan kaum Muslimin khususnya dan seluruh umat manusia pada umumnya sebagai petunjuk universal. (Ibid, V) Selain itu ditegaskan pula sebab-sebab majunya satu umat dan sebabsebab mundurnya, sebab kuat dan lemahnya, sebab tegaknya dan jatuhnya, sebab hidup dan matinya. Demikian itu dengan mengambil 
'ibrah dan pengajaran dari sejarah umat terdahulu.

Mahmud Yunus juga menegaskan bahwa jika tafsir ini dan isi kesimpulan Al Qur'an yang disertakan di dalamnya memilki nilai kebenaran, maka hal itu semata-mata merupakan hidayah dan karunia Allah. Sebaliknya, jika terdapat kekhilafan dan kesalahan maka kesalah tersebut tidak lain merupakan kesalahan dari dirinya sendiri. Sehingga beliau di dalam pendahuluan tafsirnya berdoa: "Ya Tuhan kami, jangan siksa kami jika kami lupa atau salah. Ya Tuhan kami, sesungguhnya Engkau Maha Mendengar lagi Maha Mengetahui. Dan terimalah terima taubat kami, sesungguhnya Engkau penerima taubat lagi Maha Penyayang". (Ibid)

\section{Metode dan corak tafsir}

Membaca setiap lembar dari karya mahmud Yunus ini, maka akan dapati penyajian ulasan ayatayat Al Qur'an dalam Tafsir Al Qur'an Al Karim lebih menonjolkan aspek-aspek metode ijmali (Hal ini jika mengikuti teori yang diklasifikasikan oleh Al Farmawi yang membagi menjadi empat metode tafsir, yaitu: tahlili, ijmali, muqaran dan maudhu'i. Lihat Abu Hayy Al Farmawi: 1976, 17). Metode ijmali adalah suatu penafsiran ayat-ayat Al Qur'an, di mana penjelasan yang dilakukan cukup singkat dan global. Dengan kata lain penafsiran dengan metode ini berusaha menjelaskan ayat-ayat $A$ I Qur'an secara ringkas tapi dengan menggunakan bahasa yang popular, mudah dimengerti dan enak dibaca. Sedangkan mufassir diharapkan dapat menghidangkan makna-makna dalam bingkai suasana Qur'ani. (M Quraish Shihab: 2013), 381) Maksudnya, penyajian tafsir dengan metode ini tidak terlalu jauh dari gaya bahasa Al Qur'an sehingga pendengar dan pembacanya seakan-akan masih tetap mendengar AI Qur'an. (Fahd Ibn 'Abdurrahman Ar Rumi: Tt, 59) Sehingga dengan penggunaan metode ini, akan timbul kesan mirip dengan terjemahan secara tafsir (At Tarjamah At Tafsiriyah). (Tim FKI RADEN: 2011, 228)

Penggunaan metode ini bermanfaat bagi pembaca muslim 
Khairunnas J amal; Wawasan Keindonesiaan Dalam Tafsir Al Qur'an Al Karim Karya Muhammad Yunus

yang tidak berkesampatan belajar Al Qur'an dari aspek tata bahasa, balaghah, dan berbagai disiplin ilmu lain yang berkaitan dengan Al Qur'an secara mendetail. Metode ini juga cocok bagi pemula yang baru memperlajari tafsir karena penggunaan bahasanya yang tidak terlalu bertele-tele. Hal ini sesuai dengan tujuan dari penulisan karya tafsir ini, yaitu untuk memberikan kemudahan bagi pembaca dengan penyajian yang ringkas dan sesuai untuk orang yang ingin lekas dan cepat memahami kandungan Al Qur'an.

Dalam upaya menghadirkan makna-makna yang terkandung dalam setiap ayat Al Qur'am, Mahmud Yunus tampak kecenderungannya menggunakan kekuatan nalarnya (ra'yi). Namun beliau juga berusaha menampilkan riwayat-riwayat yang berkenaan dengan penjelasan makna suatu ayat, meskipun relatif sedikit jumlahnya.

Selanjutnya, berkenaan dengan corak tafsir -yang merupakan tujuan instruksional dari suatu penafsiran- (Nashiruddin Baidan: 1998, 10)- yang coba ia tuangkan dalam karya tafsirnya nampak kecenderungannya pada aspek-aspek sosial kemasyarakatan (ijtima'i), yaitu suatu kecenderungan yang berusha menafsirkan Al Qur'an dengan keadaan sosial masyarakat yang ada di sekitar penafsir. (Tim FKI Raden: 2011, 250.) Dan jika mengkuti klasifikasi yang dibuat oleh Muhammad Amin Suma, maka dapatlah dikatakan Mahmud Yunus lebih berorientasi pada bidang keahliannya, yaitu kependidikan dan akhlak (corak tarbawi akhlaqi). (Muhammad Amin Suma: 2014, 398-399) (Bandingkan dengan Nashiruddin Baidan: 2004, 386) Mengingat Mahmud Yunus terlihat mencoba memunculkan aspek-aspek pendidikan dan pesan etik moral seperti apa saja yang terkandung dari setiap ayat yang ia tafsirkan.

\section{WAWASAN KEINDONESIAAN}

Setiap hasil karya dalam bidang apa pun, dapat dikatakan tidak akan terlepas dari wacana dan kepentingan di balik penulisannya,begitu juga dengan karya tafsir. Hal ini juga 
menunjukkan dan meneguhkan bahwa karya tafsir tidaklah muncul dari dan dalam ruang hampa yang bebas dari berbagai beban kepentingan (sosial, ekonomi bahkan politik), (Islah Gusmian: $2013,8)$ tidak terkecuali tafsir yang ditulis oleh Mahmud Yunus.

Tafsir Al Qur'an Al Karim, sebagaimana diungkapkan di atas, bahwa penulisannya merupakan sebagai respon atas kurangnya referensi tafsir Al Qur'an berbahasa Indonesia yang mudah dipahami dan ringkas. $\mathrm{Di}$ sisi lain, nampaknya karya ini merupakan respon atas gejala-gejala sosial yang berlaku di tengah masyarakat atau Indonesia pada umumnya. Sehingga tidak salah jika dikatakan tafsir ini kental dengan nuansa keindonesiaan, maksudnya adalah cenderung merespon isu-isu yang berkembang saat tafsir ini ditulis. Berikut akan disampaikan beberapa petikan yang menggambarkan hal tersebut. Misalnya saat menafsirkan ayat 65 surat AI Hajj:

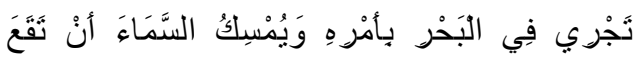

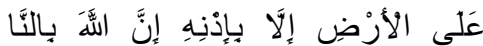
رَجيخ

"Tiadakah kamu tahu, bahwa Allah menyerahkan kepadamu apa-apa yang di bumi dan kapal yang berlayar di laut dengan perintahNya.Dia menahan langit, supaya (jangan) jatuh ke bumi, melainkan dengan izin-Nya.Sesungguhnya Allah Penyantun lagi Penyayang kepada manusia". (Terjemahan ayat Al Qur'an dalam tulisan ini merujuk pada terjemahan AI Qur'an Mahmud Yunus. Lihat Mahmud Yunus: 1975) (Bandingkan dengan terjemahan Departemen Agama Republik Indonesia.)

Mahmud

Yunus

menerangkan ayat ini, bahwa Allah memudahkan bagi manusia mempergunakan apa-apa yang ada dalam bumi untuk kemaslahatan, seperti tambang-tambang atau batu arang, emas, perak, timah, minyak dll. Semuanya itu dapat dikeluarkan dari dalam tanah, jika manusia mempergunakan akal dan pikiran, bagaimana mengeluarkannya. Sungguh aneh sekali, bahwa orang-orang yang pandai mengeluarkan barangbarang tambang itu ialah orang yang tidak mempunyai kitab Al Qur'an, seperti bangsa Barat. Sedangkan kaum Muslimin yang membaca Al Qur'an tiapa-tiapa hari 
Khairunnas J amal; Wawasan Keindonesiaan Dalam Tafsir Al Qur'an Al Karim Karya Muhammad Yunus

lengah dan tiada pandai mengeluarkannya. Seolah-olah petunjuk Al Qur'an itu dituntut oleh mereka itu, sedangkan kaum Muslimin tiada mengindahkannya. Begitu juga Allah memudahkan mempergunakan kapal untuk berlayar di lautan yang amat penting untuk pengangkutandari satu negeri ke negeri yang lain. Memang dahulu kaum Muslimin telah melaksanakan petunjuk Al Qur'an ini, sehingga mereka mengembara dan berlayar ke barat dan ke timur untuk memajukan perdagangan dan penyiaran Islam. Dengan jalan begitu tersiarlah agama Islam sampai ke India, Tiongkok, Indonesia dll. Tetapi kemudian kaum Muslimin mundur dalam pelayaran, digantikan oleh bangsa Barat, sehingga sekarang mereka memegang pusat-pusat perekonomian seluruh dunia. Hal itu patut menginsafkan kaum Muslimin, supaya mereka mementingkan perusahaan pelayaran ini, agar dapat menandingi perekonomian Barat dengan berangsur-angsur, sedikit demi sedikit, akhirnya dapat

menyamai mereka.Memang kita kaum Muslimin, terutama kaum Muslimin Indonesia, terlalu mundur sekali dalam soal perekonomian. Diantara sebab-sebabnya ialah karena fatwa-fatwa setengah ulama, bahwa kita kaum Muslimin harus mementingkan akhirat saja, karena di dunia ini adalah surga bagi orang-orang kafir dan tangsi (penjara) bagi orang-orang mu'min. Akhirnya kaum Muslimin sangat lemah dam mundur, bukan hanya dalam perekonomian, bahkan juga dalam segala hal, seperti soal pendidikan dan pengajaran dan sebagainya. (Mahmud Yunus: 2004, 492-493)

Selain itu, Mahmud Yunus menerangkan ayat Al Qur'an dengan menghubungkannya dengan keadaan Indonesia pada saat itu dan tampak penekanannya pada bidang yang memang menjadi bidang keahliannya, yaitu pendidikan. Misalnya saat menerangkan ayat 1-5 surat $\mathrm{Al}$ 'Alaq:

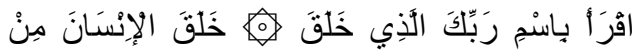

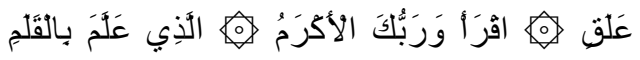

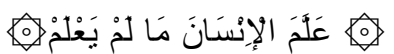
"Bacalah (ya Muhammad) dengan nama Tuhanmu yang telah 
menciptakan. Telah menciptakan manusia dari segumpal darah.Bacalah dan Tuhanmu amat pemurah. Yang mengajarkan (menulis) dengan pena. Yang mengajarkan kepada manusia apaapa yang tiada diketahuinya".

\section{Mahmud Yunus}

menerangkan bahwa surat inilah yang mula-mula turun kepada Nabi Muhammad, yaitu ketika beliau berada di tas bukit di gua Hira di negeri Makkah. Adapaun Nabi Muhammad semenjak kecilnya tidak pernah menyembah berhala, sebagaimana diperbuat oleh kaumnya. Setelah ia berumur 40 tahun, maka pergilah ia ke gua Hira itu, sambil mengingat Allah dan bersedih hati memikirkan nasib kaumnya yang telah rusak dan binasa kepercayaannya, pergaulannya dan budi pekertinya. Ketika Nabi Muhammad mengingat Allah di dalam gua Hira itu, sekonyong-konyong datanglah Jibril menyampaikan wahyu yang mula-mula, lalu ia berkata kepada Nabi Muhammad: "bacalah!" maka jawaban Nabi Muhammad: "saya tidak pandai membaca". Lalu ia berkata lagi demikian sampai berulang tiga kali. Akhirnya dibacakan oleh Jibril kepada Nabi
Muhammad surat Al 'Alaq ini, mulai ayat 1 sampai 5 .

Lebih lanjut Mahmud Yunus menerangkan, ayat ini menganjurkan kepada kita, supaya tiap-tiap orang baik putra maupun putri mestilah pandai membaca dan menulis dengan pena (kalam). Oleh sebab itu di negeri-negeri yang berkemajuan telah diadakan suatu peraturan yaitu mewjibkan para orang tua untuk memasukkan anak-anaknya ke sekolah, sekurang-kurangnya ke sekolahsekolah dasar, supaya setiap orang pandai membaca dan menulis. Di Jepang yang berdekatan dengan Indonesia, sekitar $\quad 99 \%$ penduduknya sudah pandai baca tulis, sedangkan orang yang buta huruf hanya $1 \%$ saja, yaitu tiap-tiap dalam 100 orang hanya seorang saja yang buta huruf. Sedangkan di Indoensia yang kebanyakan penduduknya muslim hanya sekitar $7 \%$ orang yang pandai tulis baca. Jadi jumlah yang buta huruf 93\%.Bukankah hal ini menjadi suatu ironi bagi kaum Muslimin, padahalAI Qur'an menganjurkan supaya tiap-tiap orang pandai tulis 
Khairunnas J amal; Wawasan Keindonesiaan Dalam Tafsir AI Qur'an Al Karim Karya Muhammad Yunus

baca. (hal ini sekitar tahun 1935 waktu mulai mengarang tafsir ini).

Oleh sebab itu kita serukan supaya tiap-tiap negeri diadakan sekolah bagi orang-orang dewasa. Sedang tiap-tiap orang tua hendaklah memasukkan anakanaknya ke sekolah. Jika pemerintah tidak mewajibkan yang demikian, cukuplah hati sanubari kita memerlukannya, karena yang diwajibkan oleh diri sendiri itu terlebih kuat dari yang diwajibkan oleh orang lain.

Adapun hikmah Nabi Muhammad tidak pandai baca tulis, ialah karena itu suatu mukjizat baginya, karena kalau ia pandai baca tulis, tentu aka nada tuduhan orang, bahwa Al Qur'an ini disalinya dari kitab Taurat, Injil dan lain-lainnya. (Ibid, 910-911)

Contoh lainnya adalah merespon pemikiran sebagian ulama Indonesia yang tengah berkembang saat itu, mislanya pada penafsiran ayat tentang kewajiban menutup aurat bagi perempuan dalam surat An Nur ayat 31 . (Ibid, 89)

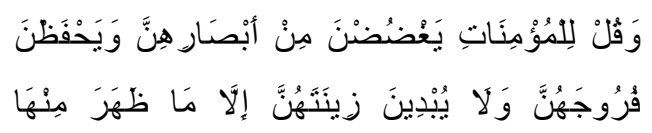

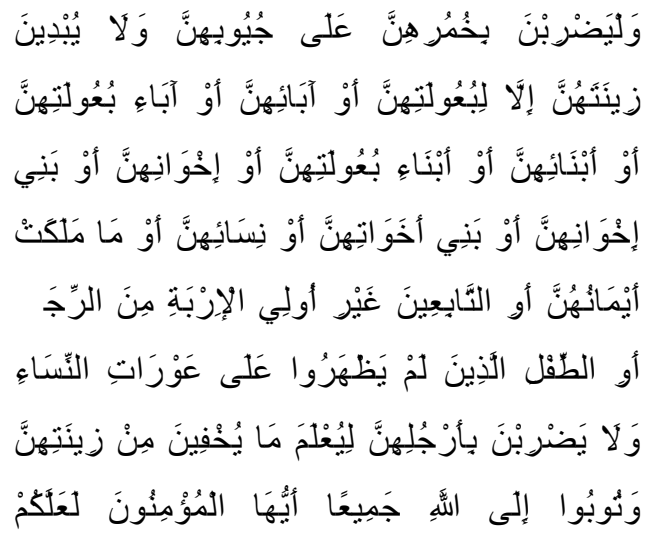

"Katakanlah kepada orang-orang beriman perempuan, supaya mereka merendahkan pemandangannya dan menjaga kehormatannya, dan janganlah, mereka memperlihatkan perhiasannya, kecuali apa yang biasa lahir daripadanya, dan hendaklah mereka tutupkan kudungnya ke lehernya. J anganlah mereka mmeperlihatkan perhiasannya, kecuali kepada suaminya, bapaknya, bapak suaminya, anaknya, anak suaminya, saudaranya, anak saudaranya yang laki-laki, anak saudaranya yang perempuan, perempuan muslimat, hamba sahayanya, orang-orang yang mengikutinya diantara laki-laki, yang tiada berhajat (syahwat) kepada perempuan atau kanakkanak yang belum (ingin) melihat aurat perempuan. Janganlah mereka berjalan sambil menggoyangkan kakinya, supaya diketahui orang perhiasannya yang tersembunyi (gelang kaki). Bertaubatlah kamu sekalian kepada Allah, hai orang-orang beriman, mudah-mudahan kamu mendapat kemenangan". 
Dikatakan bahwa hendaklah perempuan itu menutup dada dan kuduknya dengan kerudung (telekung atau tutup kepala). Para ulama telah sepakat, bahwa menutup kepala, kuduk dan dada adalah wajib, dan berdosa membukanya kepada laki-laki yang bukan famili. Adapun karib kerabat (famili) yang boleh membukakan badan kepadanya ialah: suami, boleh perempuan membukakan semua badannya kepada suaminya, bapak dan neneknya, bapak suaminya, anaknya, anak suaminya (anak tiri) saudaranya dan anak saudaranya laki-laki maupun perempuan.

Begitu juga boleh perempuan membukakan badannya kepada sesama perempuan muslimat atau kepada hamba sahayanya dan orang-orang yang tiada bersyahwat (bernafsu) kepada perempuan. Umpamanya orang yang telah sangat tua, begitu pula kepada anak-anak yang belum mengetahui aurat (kemaluan) perempuan. Maka boleh membukakan badan kepada orangorang tersebut itu, kecuali pusat dan lutut.
Hanya, di sini ada pemikiran ulama Indonesia, yaitu bahwa suruhan menutup kepala itu ialah suruhan tentang peradaban pakaian perempuan yang biasa di tanah Arab. Oleh karena itu, suruhan itu adalah suruhan sunah, bukan suruhan wajib karena dalam ilmu ushul figh tidak ditetapkan bahwa suruhan yang bersangkut dengan peradaban ialah suruhan sunah. Umpanya sebelum ayat ini (yaitu 27-29 surat An Nur) ada termaktub suruhan tentang peradaban bahwa masuk ke dalam sebuah rumah harus minta izin lebih dahulu dan mengucapkan salam. Ulama-ulama telah sepakat bahwa mengucapkan salam itu bukan hal wajib, melainkan sunah. Begitu juga sesudah ayat ini (yaitu ayat 32), ada pula suruhan menikah, sedang ulama-ulama telah menetapkan bahwa suruhan itu sunah pula. Tapi umumnya ulama menetapkan suruhan itu, suruhan wajib. (Ibid, 516-517)

Melihat kutipan beberapa segmen dari penafsiran Mahmud Yunus di atas, jelaslah bahwa penjelasan dari setiap ayat yang ia berikan merupakan bentuk dari 
Khairunnas J amal; Wawasan Keindonesiaan Dalam Tafsir Al Qur'an Al Karim Karya Muhammad Yunus

jawaban bagi kegelisahannya atas kondisi sosial masyarakat Indonesia pada umumnya. Dengan harapan dari wacana yang coba digagasnya akan memberikan pencerahan dan mendekatkan pada pemahaman. Terlebih dengan pendekatan yang digali dari nilainilai qur'ani, akan lebih memberikan kesan mendalam bagi bentuk-bentuk penyikapan terhadap realita yang berlaku.

\section{E. KESIMPULAN}

Sebagai karya tafsir yang merupakan pionir dalam kajian tafsir asli berbahasa Indonesia lengkap, Tafsir AI Qur'an Al Karim yang ditulis oleh Mahmus Yunus disajikan dengan ringkas dan relatif detail jika dibandingkan dengan karya-karya terdahulu maupun yang sezaman dengannya. Meskipun sebagian pemerhati memandangnya lebih terkesan berbentuk terjemahan Al Qur'an saja. Penggunaan cacatan kaki untuk menjelaskan maksud kata dalam ayat merupakan salah satu keunggulannya. Selain itu, karya tafsir ini dilengkapi dengan indeks rangkuman isi kadungan Al Qur'an yang dapat mempermudah untuk dipelajari.

Karya Mahmud Yunus ini terasa sangat kental dengan nuansa keindonesiaan, terutama terkait dengan dinamika keadaan sosial masyakarat yang berkembang di era penulisannya. Tidak lain karena di dalamnya merupakan suatu ungkapan respon atas kondisi yang ada. Sehingga terlihat fungsi Al Qur'an yang up to date dan fleksibel terhadap zaman. Mahmud Yunus ingin memunculkan Al Qur'an sebagai kitab petunjuk yang sesungguhnya bagi kehidupan.

\section{DAFTAR PUSTAKA}

Anwar, Endang Saipul. Telaah Terhadap Al Qur'an dan Tafsirnya (Karya Tim Penyempurna Departemen Agama Republik Indonesia.. Jjurnal Adz Dzkira vol. 01, No. 01 (Januari-Juni) 2010.

Baidan, Nashiruddin. Metodologi Penafsiran Al Qur'an. Yogyakarta: Pustaka Pelajar. Baidan. 1998.

Baidan, Nashiruddin. Wawasan Baru Ilmu Tafsir. Yogyakarta: Pustaka Pelajar. 2004.

Eficandara Masril, Mohd. Nasran Mohammad, Muhammad Adib Syamsuddin dan Anwar Fakhri Omar. Prof. 
Dr. Mahmud Yunus: Tokoh Mujaddid dari Minangkabau. Selangor: Jabatan Syariah, Fakulti Pengkajian Islam, UKM, 2011.

Al Farmawi, Abu Hayy. Bidayah fi At Tafsir Al Maudhu'i, Dirasah Manhajiyah Maudhu'iyah. t.tp, 1976.

Federspiel, Howard M. Popular Indonesian Literature of the Qur'an terj. Bandung: Mizan. 1996.

Firdaus. Sifat-Sifat Guru dalam Pandangan Mahmud Yunus; (Tinjauan PsikologisPedagogis). Pekanbaru: Program Pasca Sarjana UIN SUSKA Riau. 2011.

Gusmian, Islah. Khazanah Tafsir Indonesia; dari Hermeneutika hingga Ideologi. Yogyakarta: LKIS. 2013.

Al Indunisi, Muhammad Hatta Abdul Fattah. Nasy'atu At Tafsîr bi Indûnisiya wa Tathawwurihi, Tt:Tp, 2012.

Kamal, Taufik Adnan. Rekrontruksi Sejarah Al Qur'an. Jakarta: Yayasan Abad Demokrasi. 2011.

Latif, M Sanusi . Riwayat Hidup dan Perjuangan 20 Ulama Besar Sumatera Barat. Islamic Center Sumatera Barat. 1981.

Rina, Malta. Artikel: "Pemikiran dan Karya-karya Prof. Dr. Mahmud Yunus tentang Pendidikan Islam". Padang: IImu Sejarah Pasca Sarjana UNAND. 2011.

Ar Rumi, Fahd Ibn 'Abdurrahman. Buhuts fi Ushul At Tafsir wa Manahijuhu. Riyadh: Maktabah At Taubah. tt.
Shihab, M Quraish. Kaidah Tafsir: Syarat, Ketentuan, dan Aturan yang Patut Anda Ketahui dalam Memahami Ayat-Ayat Al Qur'an. Tanggerang: Lentera Hati. 2013.

Suma, Muhammad Amin. Ulumul Qur'an. Jakarta: PT Rajawali Pers. Cet II. 2014.

Tim FKI RADEN. Al Qur'an Kita; Studi Ilmu, Sejarah dan Tafsir Kalamullah. Kediri: Lirboyo Press. 2011.

Tim Penulis IAIN Syarif Hidayatullah. Ensiklopedi Islam Indonesia. Jakarta: Djambatan. 1992.

Yunus, Mahmud. Tarjamah Qur'an Karim. Bandung: PT Al Ma'arif. cet. II.1975.

Yunus, Mahmud. Riwayat Hidup Prof. Dr. H. Mahmud Yunus. Jakarta: Hidakarya Agung. 1982.

Yunus, Mahmud. Tafsir AI Qur'an AI Karim. Jakarta: PT Hida Karya Agung. Cet. LXXIII. 2004.

Yuni, Asmi. Pemikiran Mahmud Yunus Tentang Metode Pendidikan Islam. Pekanbaru: Fakultas Tarbiyah UIN SUSKA Riau. 2011. 